\title{
THE EFFECT OF HARVESTING DATE ON SOME AGRONOMIC AND QUALITY CHARACTERISTICS OF PEANUT GROWN IN THE MEDITERRANEAN REGION OF TURKEY
}

\author{
Leyla GULLUOGLU ${ }^{1}$, Halil BAKAL ${ }^{2}$, Bihter ONAT ${ }^{3}$, Cemal KURT ${ }^{2}$,Halis ARIOGLU ${ }^{*}$ \\ ${ }^{I}$ Cukurova University, Vocational School of Ceyhan, Adana, TURKEY \\ ${ }^{2}$ Cukurova University, Faculty of Agriculture, Department of Field Crops, Adana, TURKEY \\ ${ }^{3}$ Cukurova University, Vocational School of Kozan, Adana, TURKEY \\ *Corresponding author: halis@cu.edu.tr
}

Received: 14.06.2016

\begin{abstract}
This study was conducted at the experimental area of the Department of Field Crops, Faculty of Agriculture, Cukurova University as a main crop in 2013 and 2014. The objective of this study was to determinate the effect of harvesting dates on yield and some agronomic traits, seed and oil quality of peanut (Arachis hypogea L.) grown in the Mediterranean region. The experimental design was a Randomized Complete Block Design with three replications. The Halisbey peanut variety (Virginia market type) was used as a plant material in this research. Pod yield per hectare, shelling percentage, 100-seed weight, protein and oil percentage, fatty acids (palmitic, stearic, oleic and linoleic acids) composition and oil quality (oleic acid to linoleic acid ratio, iodine value) traits were investigated. According to a two-year average, the highest pod weight $\left(84.24 \mathrm{~g} \mathrm{plant}^{-1}\right)$ and $^{-}$ pod number $\left(36.83\right.$ no. plant $\left.^{-1}\right)$ per plant was obtained when the plants were harvested at 180 days after planting (DAP). The shelling percentage and 100-seed weight increased when the harvesting was delayed. The highest pod $\left(8002.6 \mathrm{~kg} \mathrm{ha}^{-1}\right)$ was obtained when the plants were harvested at $180 \mathrm{DAP}$. The oil and protein percentage ranged from $48.66-49.66 \%$ and $24.65-25.89 \%$ respectively. The oleic and linoleic acid content varied between $\mathbf{5 1 . 5 4 - 5 4 . 9 4 \%}$ and $\mathbf{2 4 . 6 5 - 2 6 . 7 8 \%}$, respectively. Oleic acid to linoleic acid ratio (O/L) increased when the harvesting time was delayed.
\end{abstract}

Key words: Agronomic trait, Harvesting date, Oil composition, Oil quality, Peanut

\section{INTRODUCTION}

Peanut (Arachis hypogaea L.) is an important oilseed crop for vegetable oil production (Arioglu, 2014). The annual peanut production in the world is around 45 million tones (Anonymous, 2015). About two-thirds of total peanut production is crushed for oil and the remaining one-third is used in confectionery products in the world (Dwivedi et al.1993).

Peanut seeds contain $35-56 \%$ oil and $25-30 \%$ protein and $9.5-19.0 \%$ carbohydrate on a dry seed basis. In addition, they are a good source of mineral $(\mathrm{P}, \mathrm{Ca}, \mathrm{Mg}$ and $\mathrm{K}$ ) and vitamins (E, $\mathrm{K}$ and $\mathrm{B}$ group). For this reason, it is an important source of edible oil and protein for human nutrition. Peanuts are also a cheap source of protein, a good source of essential vitamins and minerals, and a component of many food products (Gulluoglu, 2011, Ingale and Shrivastava 2011, Arioglu et al. 2013 and Chowdhury et al. 2015).

Ishag (2000), Jordan et al. (2008) and Kaba et al. (2014) reported that peanut has indeterminate growth habit. For this reason, flowering and pod formation continue long time during the growing period. The peanut plants produced many flowers (18-142 flowers per plant) but, only $15-20 \%$ of flowers produced mature pods (Lim and Hamdan, 1984). Young et al. (1982) reported that total pod production continually increased with growth period, but that harvested yield reached a peak and then declined due to increased field losses at delayed the harvesting date. Peanut plants produce their pods under the soil. For this reason, it is difficult to determine maximum maturity of pods using only morphological features. Peanut pod mesocarp colors change with maturation from white (most immature) to yellow, orange, brown and black (most mature). Pattee et al. (1980) reported that "Shellout (fruit shelled)" method is based on color changes in the mesocarp and has been shown to be the most consistent indicator of maturity and yield (Arioglu, 2014).

Young et al. (1982) pointed out that typical digging losses have been estimated to be $8 \%$ of the total yield but can reach $40 \%$ at dates beyond optimal maturity. Therefore, correctly assessing peanut maturity prior to digging is essential to the economic viability of peanut 
production. Court et al. (1984) found that delayed digging increased yield, sound mature kernels, shelling percentage, and oil content. The later digging dates produced seeds with a higher proportion of oleic acid.

Sattayarak (1997) pointed out that harvesting dates exhibited certain effects on yield, 100 seed weight, shelling percentage, oil and protein contents in peanut. Knauft et al. (1986) reported that shelling percentage, 100 -seed weight and pod yield increased when harvesting was delayed, but oil content was decreased. Canavar and Kaynak (2013) reported that, pod number and pod yield per plant, 100 seed weight, shelling percentage, pod yield, oil content protein content, $\mathrm{O} / \mathrm{L}$ ratios were increased by delaying the harvesting time.

Lu et al. (1997) reported that the lowest pod and seed yield, oil and protein content were found in the earliest harvested peanuts. Wright and Porter (1991) and Kaba et al. (2014) indicated that harvesting peanut too early reduced yield by $15 \%$ and economic value by $21 \%$. Therefore, it is very important to harvest the peanut plant at an appropriate time in order to reduce yield losses.

Andersen and Gorbet (2002) and Chowdhury et al. (2015) reported that the nutritional and storage qualities of peanut are determined by its fatty acids composition. The amount of saturated and unsaturated fatty acids in peanut oil varies from $10.92 \%$ to $17.47 \%$ and from $81.13 \%$ to $94.81 \%$, respectively. The major fatty acids components are oleic acid, linoleic acid and palmitic acid in peanut oil. Peanut oil is rich in oleic and linoleic acids. Oleic acid content in peanut genotypes can vary from $21 \%$ to $85 \%$ and linoleic acid from $2 \%$ to $43 \%$.

Young and Worthington (1974), Dwivedi et al. (1996) and Isleib et al. (2008) reported that fatty acid composition of peanut seed oil is influenced by varietal and seasonal variation, genotypic variation, air and soil temperature, planting date, soil nutrient, growing conditions and maturity.

Young et al. (1972) grew eight different peanut cultivars in Oklahoma for one year to assess effects of digging date on oil quality. Digging delays tended to give peanut oil with higher stearic and oleic acid and less linoleic acid. This relationship gave higher $\mathrm{O} / \mathrm{L}$ ratios in later diggings, indicating that the oil from these diggings would be more stable.

Knauft et al. (1988) pointed out that early digging of peanuts can be beneficial production practice when disease pressure is sever. Digging delays tended to give peanut oil with higher stearic and oleic acid and less linoleic acid. This relationship gave higher $\mathrm{O} / \mathrm{L}$ ratios in later diggings, indicating that the oil from these diggings would be more stable. Andersen and Gorbet (2002) reported that, seed maturity can also influence the fatty acid composition of peanut. In general, oleic acid increases and linoleic acid decrease with seed maturity. The increase in oleic acid with seed maturity is normally accompanied by a decrease in palmitic and linoleic acid. Bovi (1982) Raheja et al. (1987) and Önemli (2012) reported that there was a negative correlation between oleic acid and linoleic acid.

The objective of the study is to investigate the effect of harvesting times on various traits of peanut grown in Mediterranean Region of Turkey.

\section{MATERIALS AND METHODS}

\section{Materials}

Field experiments were conducted in 2013 and 2014 as a main crop, between April and October at the Cukurova University research farm in Adana, Turkey (Southern Turkey, $36^{0} 59^{1} \mathrm{~N}, 35^{\circ} 18^{1} \mathrm{E}, 23$ elevation). Halisbey peanut (Arachis hypogaea var. hypogaea) variety (Virginia market type) was used as plant material in this research.

The texture of the soil was clay loam. The soil tests in both years indicated a $\mathrm{pH}$ of 7.7 with high concentrations of $\mathrm{K}_{2} \mathrm{O}$ and low concentrations of $\mathrm{P}_{2} \mathrm{O}_{5}$. In addition, the organic matter and nitrogen content of the soil were very low. The lime content was $22.3 \%$ in the upper layers with increased levels in lower layers.

In the Adana province (Mediterranean Region) of Turkey, winters are mild and rainy, whereas summers are dry and warm, which is a typical of a Mediterranean climate. The average monthly air temperature during the research period (April-October) was $18.1^{\circ} \mathrm{C}$ to $28.6^{\circ} \mathrm{C}$ in 2013 and $18.3^{\circ} \mathrm{C}$ to $29.1^{\circ} \mathrm{C}$ in 2014 . The total rainfall was $132.4 \mathrm{~mm}$ and $191.5 \mathrm{~mm}$ during the growing periods in 2013 and 2014, respectively. The average relative humidity ranged from $47.9 \%$ to $72.3 \%$ in 2013 and $62.9 \%$ to $72.6 \%$ in 2014 . The differences between the years and long term for the climatic data were not significant (Table $1)$.

Table 1. The average monthly temperature, monthly precipitation and relative humidity during the 2013, 2014 and long term (19502015) growing seasons in Adana, Turkey (Anonymous, 2014).

\begin{tabular}{lccccccccc}
\hline \multirow{2}{*}{ Months } & \multicolumn{3}{c}{ Avg. temperature $\left({ }^{\mathbf{0}} \mathbf{C}\right)$} & \multicolumn{3}{c}{ Precipitation $(\mathbf{m m})$} & \multicolumn{3}{c}{ Relative humidity $(\%)$} \\
\cline { 2 - 10 } & $\mathbf{2 0 1 3}$ & $\mathbf{2 0 1 4}$ & LT $^{*}$ & $\mathbf{2 0 1 3}$ & $\mathbf{2 0 1 4}$ & LT $^{*}$ & $\mathbf{2 0 1 3}$ & $\mathbf{2 0 1 4}$ & LT* \\
\hline April & 18.1 & 18.3 & 17.5 & 43.2 & 18.6 & 54.7 & 72.0 & 69.2 & 67.3 \\
May & 22.7 & 21.3 & 21.7 & 57.4 & 22.4 & 47.6 & 72.3 & 70.4 & 66.9 \\
June & 25.3 & 24.8 & 25.6 & 0.3 & 1.7 & 19.8 & 65.7 & 70.5 & 68.0 \\
July & 28.2 & 28.2 & 28.1 & 0.0 & 0.3 & 7.0 & 65.2 & 72.6 & 71.6 \\
August & 28.6 & 29.1 & 28.5 & 0.0 & 0.3 & 5.3 & 69.0 & 70.3 & 71.0 \\
September & 25.3 & 25.9 & 25.9 & 15.0 & 80.4 & 17.6 & 63.1 & 64.1 & 65.4 \\
October & 19.5 & 21.0 & 21.3 & 16.5 & 67.8 & 40.6 & 47.9 & 62.9 & 61.6 \\
\hline *LT:
\end{tabular}




\section{Method}

The experiment was designed at Randomized Complete Block replicated three times. The experimental site was cultivated deeply by the moldboard following the harvest of the previous crop in the autumn and then the soil was prepared by using disked-harrowed the day of planting in both years. Before planting, $250 \mathrm{~kg} \mathrm{ha}^{-1}$ of DAP (45 kg ha ${ }^{-1} \mathrm{~N}, 115 \mathrm{~kg} \mathrm{ha}^{-1} \mathrm{P}_{2} \mathrm{O}_{5}$ ) fertilizers were applied in both years. Amonium nitrate $(33 \% \mathrm{~N})$ at the rates of $200 \mathrm{~kg} \mathrm{ha}^{-1}$ was applied two times; before first and second irrigation. Plots consisted of 4 rows $5.0 \mathrm{~m}$ long and
$70 \mathrm{~cm}$ apart. The seeds were planted by hand in the first week of April ( $5^{\text {th }}$ of April) in each year of the study, with $70 \times 15 \mathrm{~cm}$ distance. During the growing period, recommended pesticides and fungicides were applied to control insects and diseases. During the growing period, other standard cultural practices were applied at proper time intervals with according to recommendations of regional agricultural experiment station.

The plants were harvested by hand at six different times with one week intervals at the beginning of September (Table 2).

Table 2. Planting date, emergence date, harvesting dates and harvesting times (Days after planting-DAP) in the experiments in both years.

\begin{tabular}{|c|c|c|c|c|}
\hline Planting date & Emergence date & & rvesting dates & $\begin{array}{l}\text { Harvesting times (Days } \\
\text { after planting) }\end{array}$ \\
\hline \multirow{6}{*}{ April 4, 2013 and 2014} & \multirow{6}{*}{ April 20, 2013 and 2014} & (1) & September, 1 & 148 \\
\hline & & (2) & September, 8 & 156 \\
\hline & & (3) & September, 16 & 164 \\
\hline & & (4) & September, 23 & 172 \\
\hline & & $(5)$ & September, 30 & 180 \\
\hline & & (6) & October, 7 & 188 \\
\hline
\end{tabular}

\section{Measurement of Characteristics}

Per plant data were measured from the 20 plants that were randomly selected from the central rows of each plot and then harvested by hand. Average pod number (no. plant $\left.^{-1}\right)$ and pod weight $\left(\mathrm{g} \mathrm{plant}^{-1}\right)$ were calculated as the quotient of their respective values and the number of sampled plants $(n=20)$. Per plot yield data were measured in a similar manner from all remaining plants excluding the very end on each side of the two central rows. Pod yield per hectare, selling percentage, 100-seed weight (g), protein and oil content $(\%)$, fatty acids content $(\%)$, Iodine value and $\mathrm{O} / \mathrm{L}$ ratio data were obtained after harvest.

Determination of oil percentage: Oil was extracted from peanut seeds using (Soxhlet), and oil percentage was estimated according to Association of Official Analytical chemists (AOCS, 1989).

Determination of Protein percentage: Nitrogen percentage in seeds was estimated using (Micro-Kjeldahl) method according to Association of Official Analytical chemists (A.O.A.C., 1990). Protein percentage was calculated according to the following equation: Protein percentage $=$ Nitrogen percentage $(\mathrm{N} \%) \times 6.25$

Determination of fatty acids composition: Fatty acid methyl esters were prepared according to AOCS (1989), method Ce 2-66 and analyzed with HP 6890 Series II Gas Chromatograph (GC) (Hewlett-Packard Company, Wilmington, DE, USA) equipped with a flame ionization detector and auto sampler. A fused silica capillary column
SP $2340(60 \mathrm{~m} \times 0.25 \mathrm{~mm}$ i.d. $)$ with a film thickness of $0.25 \mu \mathrm{m}$ (Supelco, Taufkirchen, Germany) was used. Injection, detector, and oven temperatures were 250, 260, and $190^{\circ} \mathrm{C}$, respectively. Nitrogen was used as a carrier

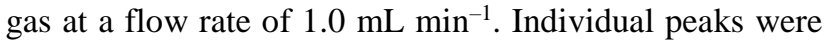
identified by comparing the retention times with grain fatty acid methyl esters.

Iodine values (IV) of the peanut oils were calculated using the equation given by Hashim et al. (1993).

$$
\mathrm{IV}=\left(\% \mathrm{C}_{18: 1} \times 0.8601\right)+\left(\% \mathrm{C}_{18: 2} \times 1.7321\right)
$$

Determination of Maturity index (\%): It was determined using "Shellout" method based on color changes in the mesocarp of peanut pods. The maturity index (the percentage of brown and black pods) was calculated by brown and black mesocarp color Pod number / Total pods number (Arioglu, 2014).

The data were statistically analyzed by using JUMP 8.1.0 package program with Randomized Complete Block Design. The Least Significant Differences (LSD) test was used to compare the treatments at 0.05 level.

\section{RESULTS AND DISCUSSSION}

\section{Pod yield and Pod number per plant}

The data belonging to pod yield and pod number per plant at different harvesting times in main cropped peanut production has been presented in Table 3 . 
Table 3. The effect of harvesting times on pod yield $\left(\mathrm{g} \mathrm{plant}^{-1}\right)$ and pod number (no. plant ${ }^{-1}$ ) per plant of peanut production in 2013 , 2014 and two years average in Adana, Turkey

\begin{tabular}{|c|c|c|c|c|c|c|}
\hline \multirow{2}{*}{$\begin{array}{l}\text { Harvesting times } \\
\text { (DAP) }\end{array}$} & \multicolumn{3}{|c|}{ Pod yield $\left(\mathrm{g} \mathrm{plant}^{-1}\right)$} & \multicolumn{3}{|c|}{ Pod number (no. plant $^{-1}$ ) } \\
\hline & 2013 & 2014 & Average & 2013 & 2014 & Average \\
\hline 148 & $62.35 \mathrm{~d}$ & $65.57 \mathrm{e}$ & $63.96 \mathrm{~d}$ & $29.40 \mathrm{c}$ & $30.38 \mathrm{e}$ & $29.89 \mathrm{~d}$ \\
\hline 156 & $69.24 \mathrm{~cd}$ & $70.43 \mathrm{~d}$ & $69.83 \mathrm{c}$ & $32.97 \mathrm{~b}$ & $33.70 \mathrm{~d}$ & $33.33 \mathrm{c}$ \\
\hline 164 & $77.50 \mathrm{bc}$ & $75.25 \mathrm{c}$ & $76.38 \mathrm{~b}$ & $34.14 \mathrm{ab}$ & $34.34 \mathrm{~cd}$ & $34.24 \mathrm{bc}$ \\
\hline 172 & $81.29 \mathrm{ab}$ & $78.50 \mathrm{ab}$ & $79.90 \mathrm{~b}$ & $35.25 \mathrm{ab}$ & $35.56 \mathrm{ab}$ & $35.40 \mathrm{ab}$ \\
\hline 180 & $87.58 \mathrm{a}$ & $80.90 \mathrm{a}$ & $84.24 \mathrm{a}$ & $36.96 \mathrm{a}$ & $36.71 \mathrm{a}$ & $36.83 \mathrm{a}$ \\
\hline 188 & $80.82 \mathrm{ab}$ & $75.35 \mathrm{bc}$ & $78.08 \mathrm{~b}$ & $34.22 \mathrm{ab}$ & $34.99 \mathrm{bc}$ & $34.60 \mathrm{bc}$ \\
\hline $\operatorname{LSD}(5 \%) *$ & 8.536 & 3.158 & 4.260 & 3.329 & 1.173 & 1.652 \\
\hline
\end{tabular}

*Same letters in a column are not significantly difference at the 0.05 probability level

As it can be seen from Table 3, statistically significant differences were found among the harvest times for pod yield and pod number plant ${ }^{-1}$ in each two-year. The pod yield plant ${ }^{-1}$ values varied between $62.35-87.58 \mathrm{~g}, 65.57-$ $80.90 \mathrm{~g}$ and 63.96-84.24 $\mathrm{g}$ in 2014, 2015 and two-years average, respectively. The pod yield was increased when the harvesting time was delayed to 180 DAP. The pod yield was highest when the plants were harvested 180 DAP and after that, the pod yield started to decrease in each two-years. As the harvesting date was delayed, pod yield plant ${ }^{-1}$ increased from $63.57 \mathrm{~g}$ to $84.24 \mathrm{~g}$ at the 180 DAP and the pod yield decreased to $78.08 \mathrm{~g}$ at the 188 DAP in a two-year average (Table 3 ).

The number of pods plant $^{-1}$ varied between 29.4036.90 pods in 2014 and $30.38-36.71$ pods in 2013 . The pod number was increased when the harvesting time delayed from 148 DAP to 180 DAP and after that, pod number was decreased when the harvesting time delayed to 188 DAP in each two years. While the pods number plant $^{-1}$ was 29.89 pods when the plants harvested at the 148 DAP, it was increased to 36.83 pods plants harvested at the $180 \mathrm{DAP}$ and then, the number of pods plant ${ }^{-1}$ was decreased to 34.60 pods when the harvesting time was delayed to 188 DAP in a two-year average (Table 3 ).

According to Arioglu (2014), when the harvest is done at an early time, the pod yield can be low, since the peanut pod is not fully filled. However, when the harvest is delayed, the peanut pod can remain in the soil because of decay in the pegs of the peanut and therefore, the pod yield and pod number of peanut is decreased with an increased loss of harvest. Young et al. (1982) reported that total pod production continually increased with growth period, but that harvested yield reached a peak and then decline due to increased field losses at the longer period. Delay in harvesting after physiological maturity can result in many pods left in the soil due to weakening of pegs. Similar results were reported by other researchers (Court et al. 1984; Knauft et al. 1986; Park and Oh, 1992; Lu et al. 1997; Rahmianna et al. 2009; Canavar and Kaynak, 2013 and Kaba et al. 2014).

\section{Shelling percentage and 100-Seed weight}

The data belonging to shelling percentage and 100seed weight at different harvesting times in main cropped peanut production has been presented in Table 4 .

Table 4. The effect of harvesting times on shelling percentage (\%) and 100-seed weight ( $\mathrm{g}$ ) of peanut production in 2013,2014 and two years average in Adana, Turkey

\begin{tabular}{ccccccc}
\hline Harvesting & \multicolumn{3}{c}{ Shelling percentage (\%) } & \multicolumn{3}{c}{ 100-seed weight (g) } \\
\cline { 2 - 7 } times (DAP) & $\mathbf{2 0 1 3}$ & $\mathbf{2 0 1 4}$ & Average & $\mathbf{2 0 1 3}$ & $\mathbf{2 0 1 4}$ & Average \\
\hline 148 & $62.92 \mathrm{~b}$ & $64.78 \mathrm{c}$ & $63.85 \mathrm{~d}$ & $111.08 \mathrm{~b}$ & $113.96 \mathrm{c}$ & $112.52 \mathrm{c}$ \\
156 & $63.53 \mathrm{ab}$ & $65.43 \mathrm{c}$ & $64.48 \mathrm{~cd}$ & $120.94 \mathrm{a}$ & $120.39 \mathrm{bc}$ & $120.66 \mathrm{~b}$ \\
164 & $64.16 \mathrm{ab}$ & $66.16 \mathrm{bc}$ & $65.16 \mathrm{bcd}$ & $124.32 \mathrm{a}$ & $123.35 \mathrm{ab}$ & $123.84 \mathrm{ab}$ \\
172 & $64.49 \mathrm{ab}$ & $66.95 \mathrm{ab}$ & $65.72 \mathrm{abc}$ & $125.77 \mathrm{a}$ & $124.20 \mathrm{ab}$ & $124.99 \mathrm{ab}$ \\
180 & $66.08 \mathrm{a}$ & $67.09 \mathrm{ab}$ & $66.58 \mathrm{ab}$ & $126.55 \mathrm{a}$ & $126.07 \mathrm{ab}$ & $126.32 \mathrm{a}$ \\
188 & $66.43 \mathrm{a}$ & $67.70 \mathrm{a}$ & $67.07 \mathrm{a}$ & $127.19 \mathrm{a}$ & $129.89 \mathrm{a}$ & $128.54 \mathrm{a}$ \\
LSD $(5 \%) *$ & 2.954 & 1.495 & 1.550 & 6.683 & 9.334 & 5.374 \\
\hline
\end{tabular}

*Same letters in a column are not significantly difference at the 0.05 probability level

The differences between the harvesting times were statistically significant for the shelling percentage in both years and in a two-year average. The shelling percentage values varied between $62.92-66.43 \%$ in 2014 , 64.78$67.70 \%$ in 2015 and $63.85-67.07 \%$ in a two-year average. The shelling percentage was higher in 2014 than in 2013. The shelling percentage increased when the harvesting time was delayed in peanut production. The shelling percentage reaches to maximum level at the physiological maturity of pods. Shelling percentages were higher at each subsequent harvesting date. Overall the shelling percentage increased from $63.85 \%$ for the first harvesting date (148 DAP) to $67.07 \%$ for the sixth harvesting date (188 DAP) in two years average. 
Court et al. (1984), Mixon and Branch (1985), Sattayarak (1997), Knauft et al. (1986) and Canavar and Kaynak (2013) reported that shelling percentage increased when harvesting was delayed.

There was statistically significant difference in 100seed weights between harvesting times in both years and two years average. The 100-seed weight values varied between 111.08-127.19 $\mathrm{g}$ in 2013, between 113.96-129.89 $\mathrm{g}$ in 2014 and between 112.52-128.54 $\mathrm{g}$ in a two-year average (Table 4). By delaying harvesting time, the 100seed weight was significantly increased in both years. The 100 -seed weight was increased to $14.2 \%$ when the harvesting time was delayed from 148 DAP to 188 DAP and the highest 100 -seed weight increase $(8.14 \mathrm{~g})$ was found between the first and second harvesting times in a two-year average. Peanut harvest at physiological maturity period gave better result than that earlier harvesting time for 100-seed weight. Duncan et al. (1978) suggested that the length of the pod filling period correlated with the 100-seed weight. The 100-seed weight was increased when the pod filling period extended in peanut production. Rahmianna et al. (2009) found that age of harvests significantly affected weights of pods, well filled seeds, and shriveled seeds. Therefore, it is very important to harvest the peanut plant at an appropriate time (mesocarp's color of pod is brown or black) in order to get higher 100-seed weight. There was no significant difference between the years in 100-seed weight. These results are in agreement with the findings of Mixon and Branch (1985), Knauft et al. (1986), Park and Oh (1992), Sattayarak (1997), Rahmianna et al. (2009) and Canavar and Kaynak (2013). These researchers reported that 100seed weight increased when the harvesting time was delayed.

\section{Maturity Index and Pod Yield per Hectare}

The data belonging to maturity index and pod yield per hectare at different harvesting times in main cropped peanut production has been presented in Table 5.

Table 5. The effect of harvesting times on maturity index (\%) and pod yield $\left(\mathrm{kg} \mathrm{ha}^{-1}\right)$ per hectare of peanut production in 2013,2014 and two years average in Adana, Turkey

\begin{tabular}{ccccccc}
\hline $\begin{array}{c}\text { Harvesting times } \\
\text { (DAP) }\end{array}$ & $\mathbf{2 0 1 3}$ & $\mathbf{2 0 1 4}$ & Average & $\mathbf{2 0 1 3}$ & $\mathbf{2 0 1 4}$ & Pverage \\
\cline { 2 - 7 } & $45.50 \mathrm{e}$ & $46.27 \mathrm{~d}$ & $45.88 \mathrm{f}$ & $5923.5 \mathrm{~d}$ & $6293.4 \mathrm{~d}$ & $6108.5 \mathrm{~d}$ \\
156 & $48.90 \mathrm{~d}$ & $50.40 \mathrm{c}$ & $49.65 \mathrm{e}$ & $6577.5 \mathrm{~cd}$ & $6690.5 \mathrm{c}$ & $6634.0 \mathrm{c}$ \\
164 & $52.30 \mathrm{c}$ & $52.63 \mathrm{c}$ & $52.47 \mathrm{~d}$ & $7362.5 \mathrm{bc}$ & $7148.7 \mathrm{~b}$ & $7255.6 \mathrm{~b}$ \\
172 & $55.80 \mathrm{~b}$ & $58.50 \mathrm{~b}$ & $57.15 \mathrm{c}$ & $7723.2 \mathrm{ab}$ & $7457.8 \mathrm{a}$ & $7590.5 \mathrm{~b}$ \\
180 & $61.90 \mathrm{a}$ & $62.07 \mathrm{a}$ & $61.98 \mathrm{~b}$ & $8320.1 \mathrm{a}$ & $7685.2 \mathrm{a}$ & $8002.6 \mathrm{a}$ \\
188 & $64.00 \mathrm{a}$ & $64.73 \mathrm{a}$ & $64.37 \mathrm{a}$ & $7677.2 \mathrm{ab}$ & $7157.9 \mathrm{~b}$ & $7417.6 \mathrm{~b}$ \\
LSD (5\%)* & 2.478 & 2.680 & 1.709 & 810.91 & 295.47 & 404.00 \\
\hline
\end{tabular}

*Same letters in a column are not significantly difference at the 0.05 probability level

Maturity index (\%) was determined using "Shellout" method based on color changes in the mesocarp of peanut pods. The maturity index (the percentage of brown and black pods) was calculated by brown and black mesocarp color pod number to total pods number ratio in plant ${ }^{-1}$ (Arioglu, 2014). Maturity index is an important character for the determination of optimum harvesting time (maturity) to reduce digging losses in peanut production. Therefore, correctly assessing peanut maturity prior to digging is essential to the economic viability of peanut production (Rowland et al. 2006).

Peanut plants produce their pods under the soil. For this reason, it is difficult to determine maximum maturity of pods using only morphological features. Peanut pod mesocarp colors change with maturation from white (most immature) to yellow, orange, brown and black (most mature). Sanders et al. (1980) and Pattee et al. (1980) reported that "Shellout (fruit shelled)" method is based on color changes in the mesocarp and has been shown to be the most consistent indicator of maturity and yield. Ishag (2000), Kaba et al. (2014) and Young et al. (1982) reported that peanut has indeterminate growth habit and flowering and pod formation continue long time during the growing period. For this reason, total pod production continually increased with growth period.

It can be seen in Table 5, the differences between the harvesting times were significant for maturity index in both years and in a two year average. The maturity index values varied between $45.50-64.00 \%, 46.27-64.73 \%$ and $45.88-64.37 \%$ in 2013, 2014 and two years average respectively. The maturity index was significantly increased when the harvesting time was delayed from 148 DAP to 188 DAP in both years. According to a two-year average, the maturity index was increased from $45.88 \%$ to $64.37 \%$ when the harvesting time was delayed from 148 DAP to 188 DAP. Maturity index is an important character for the determination of optimum harvesting time (maturity) to reduce digging losses in peanut production. Therefore, correctly assessing peanut maturity prior to digging is essential to the economic viability of peanut production (Rowland et al. 2006). Jordan et al. (2008) indicated that digging peanut based on pod mesocarp color continues to be effective in optimizing market grade characteristics. The yield losses increase if harvesting time is delayed after maximum pod maturity. Similar results were reported by other researchers (Court et al. 1984; Knauft et al. 1986; 
Rowland et al. 2006; Canavar and Kaynak, 2013 and Kaba et al. 2014).

There was statistically significant difference in pod yield per hectare between harvesting times in both years and two years average. The pod yield values varied between $5923.5-8320.1 \mathrm{~kg} \mathrm{ha}^{-1}$ in 2013, between 6293.4$7685.2 \mathrm{~kg} \mathrm{ha}^{-1}$ in 2014 and between $6108.5-8002.6 \mathrm{~kg} \mathrm{ha}^{-1}$ in a two-year average (Table 5). The pod yield was increased when the harvesting time was delayed in both years. While the pod yield was $6108.5 \mathrm{~kg} \mathrm{ha}^{-1}$ when the plants harvested at $148 \mathrm{DAP}$, the pod yield increased to $8002.6 \mathrm{~kg} \mathrm{ha}^{-1}$ plants harvested at $180 \mathrm{DAP}$, and then the pod yield decreased to $7417.6 \mathrm{~kg} \mathrm{ha}^{-1}$ when the harvesting time was delayed to 188 DAP in a two-year average. Early harvest (148 DAP) produced the lowest pod number. The highest pod yield was obtained from peanut harvested at 180 DAP. According to a two-year average, the pod yield was increased $31.0 \%$ when the harvesting time delayed from 148 DAP to 180 DAP. The most suitable harvesting dates for Halisbey variety were 172-180 DAP in main cropped growing season (Table 5).

The pod number was increased when the harvesting time delayed from 148 DAP to 180 DAP and after that, pod number was decreased when the harvesting time was delayed to 188 DAP in each two years (Table 3 ). The pod yield was increased when the pod number plant ${ }^{-1}$ increased. Park and Oh (1992) found that the yield was positively correlated to pod number, matured seed percent and 100 seed weight. Duncan et al. (1978) suggested that the length of the pod filling period and the rate of pod establishment is the best explain the variation in peanut yield. Rahmianna et al. (2009) found that age of harvests significantly affected weights of pods, well filled seeds, and shriveled seeds. A 10-day harvest delay resulted in $14.3 \%$ yield increases. Young et al. (1982) pointed out that typical digging losses have been estimated to be $8 \%$ of the total yield when the harvest delayed after physiological maturity of pods.

The harvesting time was delayed from 180 DAP to 188 DAP, the pod yield was decreased (7.3\%). Sing and Oswalt (1995) reported that delay in harvesting after physiological maturity can result in many pods left in the soil due to weakening of pegs.

Young et al. (1982) reported that total pod production continually increased with growth period, but that harvested yield reached a peak and then declined due to increased field losses at the longer period. Court et al. (1984) found that the pod (48.2-79.7\%) and kernel (75.4$120.7 \%$ ) yield increased when the harvest delayed from 2 September to 12 October. Wright and Porter (1991) and (Kaba et al. 2014) further indicated that harvesting peanut too early can reduced yield by $15 \%$ and economic value by $21 \%$. Therefore, it is very important to harvest the peanut plant at an appropriate time in order to reduce yield losses. Similar results were supported by findings by Court et al. (1984), Knauft et al. (1986), Sattayarak (1997), Lu et al. (1997), Rahmianna et al. (2009) and Canavar and Kaynak (2013).

\section{Oil and Protein Content}

The data belonging to oil and protein content at different harvesting times in main cropped peanut production has been presented in Table 6 .

Table 6. The effect of harvesting times on oil and protein content (\%) of peanut production in 2013, 2014 and two years average in Adana, Turkey

\begin{tabular}{ccccccc}
\hline $\begin{array}{c}\text { Harvesting times } \\
\text { (DAP) }\end{array}$ & \multicolumn{3}{c}{ Oil content $(\boldsymbol{\%})$} & \multicolumn{3}{c}{ Protein content (\%) } \\
\cline { 2 - 7 } & $\mathbf{2 0 1 3}$ & $\mathbf{2 0 1 4}$ & Average & $\mathbf{2 0 1 3}$ & $\mathbf{2 0 1 4}$ & Average \\
\hline 148 & 47.72 & 51.60 & 49.66 & 25.35 & 25.85 & 25.60 \\
156 & 47.54 & 51.50 & 49.52 & 25.64 & 26.15 & 25.89 \\
164 & 47.52 & 51.46 & 49.49 & 25.11 & 25.61 & 25.36 \\
172 & 47.50 & 50.59 & 49.04 & 24.70 & 25.53 & 25.11 \\
180 & 47.29 & 50.48 & 48.89 & 24.40 & 25.23 & 24.81 \\
188 & 47.30 & 50.02 & 48.66 & 24.37 & 24.93 & 24.65 \\
LSD (5\%)* & $\mathrm{NS}$ & $\mathrm{NS}$ & $\mathrm{NS}$ & $\mathrm{NS}$ & $\mathrm{NS}$ & $\mathrm{NS}$ \\
\hline
\end{tabular}

*Same letters in a column are not significantly difference at the 0.05 probability level

As it can be seen from Table 6, the differences between the harvesting times were not statistically significant for oil and protein content in each two-year. The oil percentage varied between $47.29-47.72 \%, 50.02-$ $51.60 \%$ and $48.66-49.66 \%$ in 2014,2015 and two-years average, respectively. The average oil content of peanut seed was greater at the first harvesting date than at the subsequent five harvesting dates. The oil percentage was reduced when the harvesting time was delayed. But, it was not statistically significant. The oil content was $45.8 \%$ at first harvesting date (September, 1) while it was $47.3 \%$ at sixth harvesting date (October, 7) in a two-year average.
The protein percentage varied between $25.64-24.37 \%$ in $2013,26.15-24.93 \%$ in 2014 and $25.89-24.65 \%$ in a two-year average. According to a two-year average, the protein percentage was increased from $25.60 \%$ to $25.89 \%$ when the harvesting time was delayed from 148 DAP to 156 DAP and then protein percentage decreased from $25.89 \%$ to $24.65 \%$ as the harvesting was delayed from 156 DAP to 188 DAP (Table 6).

Sattayarak (1997) pointed out that harvesting dates exhibited certain effects on oil and protein contents in peanut. Knauft et al. (1986) reported that oil content decreased when harvesting was delayed. Holaday and 
Pearson (1974) found that higher temperatures during the last 4 weeks before harvest resulted in higher oil content. Court et al. (1984) utilized five successive digging dates in Ontario ranging from 113 DAP over two years to examine differences in two genotypes. They found that delayed digging, increased oil content. Singh and Oswalt (1995), Lu et al. (1997) and Canavar and Kaynak (2013) reported that oil and protein content were increased by delaying the harvesting time.

\section{Fatty Acids Composition and Oil Quality}

The data belonging to saturated and unsaturated fatty acids content, oleic acid to linoleic acid ratio $(\mathrm{O} / \mathrm{L})$ and iodine values (IV) at different harvesting times in main cropped peanut production has been presented in Table 7 and 8.

Table 7. The effect of harvesting times on unsaturated fatty acids composition (\%) of peanut production in a two years average

\begin{tabular}{|c|c|c|c|c|c|}
\hline \multirow{2}{*}{ Harvesting times (DAP) } & \multicolumn{5}{|c|}{ Saturated fatty acids (\%) } \\
\hline & Palmitic & Stearic & Behenic & Arachidic & Lignoceric \\
\hline 148 & $10.06 \mathrm{a}$ & $3.01 \mathrm{e}$ & $2.83 \mathrm{~b}$ & 1.14 & 1.83 \\
\hline 156 & $10.04 \mathrm{a}$ & $3.08 \mathrm{~d}$ & $2.83 \mathrm{~b}$ & 1.12 & 1.80 \\
\hline 164 & $10.03 \mathrm{a}$ & $3.18 \mathrm{c}$ & $2.86 \mathrm{ab}$ & 1.14 & 1.80 \\
\hline 172 & $9.54 \mathrm{~b}$ & $3.31 \mathrm{~b}$ & $2.91 \mathrm{a}$ & 1.12 & 1.67 \\
\hline 180 & $9.45 \mathrm{~b}$ & $3.36 \mathrm{ab}$ & $2.88 \mathrm{ab}$ & 1.08 & 1.61 \\
\hline 188 & $9.14 \mathrm{c}$ & $3.37 \mathrm{a}$ & $2.70 \mathrm{c}$ & 1.12 & 1.54 \\
\hline$(5 \%) *$ & 0.221 & 0.055 & 0.060 & NS & NS \\
\hline
\end{tabular}

*Same letters in a column are not significantly difference at the 0.05 probability level

As it can be seen from table 7 , the differences between the harvesting times were statistically significant for the palmitic acid, stearic acid and behenic acid percentage, but it was not important for the arachidic acid and lignoceric acid percentage for a two year average. The palmitic acid, stearic acid, behenic acid, arachidic acid and lignoceric acid percentages varied between $9.14-10.06 \%$, $3.01-3.37 \%, 2.70-2.91 \%, 1.08-1.14 \%$ and $1.54-1.83 \%$, respectively in a two year average (Table 7). The stearic acid percentage increased when the harvesting date was delayed, but palmitic and lignoceric acids decreased when the harvesting time was delayed.

The oleic acid percentage varied from $51.54 \%$ to
$54.94 \%$ and linoleic acid percentage varied from $24.65 \%$ to $26.78 \%$ in a two year average (Table 8). The differences between the harvesting times were significant for the oleic and linoleic acids percentage in a two year average. While the oleic acid percentage was $51.54 \%$ at the harvesting 148 DAP, it increased up to $54.94 \%$ at the harvesting 188 DAP. As the harvesting time was delayed, the oleic acid percentage increased. However, the linoleic acid percentage was decreased from $26.78 \%$ to $24.65 \%$ when the harvesting time was delayed from 148 DAP to 188 DAP in a two year average (Table 8). As the harvesting time was delayed, the linoleic acid percentage decreased substantially.

Table 8. The effect of harvesting times on unsaturated fatty acids composition (\%), oleic to linoleic acid ratio and iodine value of peanut production in a two year average

\begin{tabular}{|c|c|c|c|c|}
\hline \multirow{2}{*}{ Harvesting times (DAP) } & \multicolumn{2}{|c|}{ Unsaturated fatty acids (\%) } & \multirow{2}{*}{ O/L ratio $* *$} & \multirow{2}{*}{ Iodine value } \\
\hline & Oleic & Linoleic & & \\
\hline 148 & $51.54 \mathrm{~d}$ & $26.78 \mathrm{a}$ & 1.92 & 90.72 \\
\hline 156 & $51.90 \mathrm{~cd}$ & $26.63 \mathrm{a}$ & 1.95 & 90.77 \\
\hline 164 & $52.32 \mathrm{c}$ & $26.40 \mathrm{a}$ & 1.98 & 90.73 \\
\hline 172 & $53.21 \mathrm{~b}$ & $25.54 \mathrm{~b}$ & 2.08 & 90.00 \\
\hline 180 & $53.45 \mathrm{~b}$ & $25.39 \mathrm{~b}$ & 2.11 & 89.95 \\
\hline 188 & $54.94 \mathrm{a}$ & $24.65 \mathrm{c}$ & 2.23 & 87.35 \\
\hline $\operatorname{LSD}(5 \%)^{*}$ & 0.616 & 0.487 & NS & NS \\
\hline
\end{tabular}

*Same letters in a column are not significantly difference at the 0.05 probability level

$* * \mathrm{O} / \mathrm{L}=$ Oleic acid / Linoleic acid ratio

The oleic acid to linoleic acid ratio (O/L) was increased when the harvesting date delayed. As the O/L ratio was 1.92 at the first harvesting time (148 DAP), it increased up to 2.23 at the sixth harvesting time (188 $\mathrm{DAP})$. The $\mathrm{O} / \mathrm{L}$ ratio was increased when the seed harvested at the full maturity. According to two years average, the iodine value varied between 87.35 and 90.72 .
The iodine value (IV) was decreased when the harvesting time delayed (Table 8).

Andersen and Gorbet (2002) and Chowdhury et al. (2015) reported that the amount of saturated and unsaturated fatty acids in peanut oil varies from $10.92 \%$ to $17.47 \%$ and from $81.13 \%$ to $94.81 \%$ respectively. The 
major fatty acids components are oleic acid, linoleic acid and palmitic acid in peanut oil. Peanut oil is rich in oleic and linoleic acids. Oleic acid content in peanut genotypes can vary from $21 \%$ to $85 \%$ and linoleic acid from $2 \%$ to $43 \%$.

Young and Worthington (1974), Dwivedi et al. (1996) and Isleib et al. (2008) reported that fatty acid composition of peanut seed oil is influenced by varietal and seasonal variation, genotypic variation, air and soil temperature, planting date, soil nutrient, growing conditions and maturity. Andersen and Gorbet (2002) reported that, seed maturity can also influence the fatty acid composition of peanut. In general, oleic acid increases and linoleic acid decrease with seed maturity. Young et al. (1972) found that digging delays tended to give peanut oil with higher stearic and oleic acid and less linoleic acid. This relationship gave higher $\mathrm{O} / \mathrm{L}$ ratios in later diggings, indicating that the oil from these diggings would be more stable. Knauft et al. (1988) pointed out that early digging of peanuts can be beneficial production practice when disease pressure is sever. Digging delays tended to give peanut oil with higher stearic and oleic acid and less linoleic acid. Bovi (1982) Raheja et al. (1987) and Önemli (2012) reported that there was a negative correlation between oleic acid and linoleic acid.

These results are in agreement with the findings of Young et al. (1972), Young and Worthington (1974), Bovi (1982), Raheja et al. (1987), Knauft et al. (1988), Hinds (1995), Dwivedi et al. (1996), Andersen and Gorbet (2002), Isleib et al. (2008), Önemli (2012) and Chowdhury et al. (2015).

\section{CONCLUSIONS}

The peanut plant has indeterminate growth habit. For this reason, flowering and pod formation continue long time during the growing period. The pod production continually increases with growth period, but the harvested yield reaches a peak and then decline due to increased field losses at the longer period. Therefore, correctly assessing peanut maturity prior to digging is essential to the economic viability of peanut production. At the harvesting time, at least $60 \%$ of the pods mesocarp color should be brown or black. The pod number and pod yield plant $^{-1}$, shelling percentage, 100-seed weight and pod yield ha-1 were increased when the harvesting time was delayed. It has been found that the optimum harvesting time is the 180 DAP in main cropped peanut production. As the harvesting time was delayed, the oil and protein percentage, linoleic acid percentage and iodine value decreased. However, oleic acid percentage and $\mathrm{O} / \mathrm{L}$ ratio were increased when the harvesting time was delayed.

\section{LITERATURE CITED}

Andersen, P.C. and D.W. Gorbet. 2002. Influence of Year and Planting Date on Fatty Acid Chemistry of High Oleic Acid and Normal Peanut Genotypes. J. Agric. Food Chem. 50:1298-1305
Anonymous, 2014. The Meteorological Data for Adana. The Turkish State Meteorological Service Adana Regional Directorship, 2013 and 2014

Anonymous, 2015. FAO Production Year Book (www.fao.org).

AOCS. 1989. Official and Recommended Methods. American oil Chemists' Society Press. Champaing, IL, USA

A.O.A.C. (1990): Association of Official Analytical Chemists Official Methods of Analysis. 1st Ed. The Association, Washington DC.USA.

Arioglu, H., C. Kurt, H. Bakal, L. Gulluoglu and N.S. Sinan. 2013. The Effect of Pix Applied at Different Growing Stages on Some Agronomical Characteristics of Peanut. Turk J Field Crops 18 (2): 260-267

Arioglu, H.H. 2014. The Oil Seed Crops Growing and Breeding. The Publication of University of Cukurova, Faculty of Agriculture, No:A-70, 204 p. Adana-Turkey

Bovi, M.L.A. 1982. Genotypic and Environmental Effect on Fatty Acid Composition, Iodine Value and Oil Content of Peanut (Arachis hypogea L.) Ph.D. Dissertation. University of Florida, p. 119.

Canavar, Ö and M.A. Kaynak. 2013. Determination of Yield and Yield Components and seed Quality of Peanuts (Arachis hypogea L.) at Different Harvest Times. Int. J. of Agronomy and Plant Production 4(S):3791-3803

Chowdhury, F.N., D. Hossain, M. Hosen and S. Rahman. 2015. Comparative Study on Chemical Composition of Five Varieties of Groundnut (Arachis hypogeal L.). World J. of Agricultural Science 11(5)247-254

Court W.A., R.C. Roy and J G. Hendel. 1984. Effect of Harvest Date on Agronomic and Chemical Characteristics of Ontario Peanuts. Canadian J. Plant Science 64:521-528

Duncan, W.G., D.E. McCloud, R.L. McGraw and K.J. Boote. 1978. Physiological Aspects of Peanut Yield Improvement. Crop Science 18:1015-1020

Dwivedi, S. L., S.N. Nigam, R. Jambunathan, K.L. Sahrawat, G.V.S. Nagabhushanam and K. Raghunath. 1996. Effect of Genotypes and Environments on Oil and Oil Quality Parameters and Their Correlation in Peanut (Arachis hypogeal L.). Peanut Science 20:84-89

Gulluoglu, L. 2011. Effects of Regulator Applications on Pod Yield and Some Agronomic Characters of Peanut in Mediterranean Region. Turk J Field Crops 16(2):210-214

Hashim, J.B., P.E. Koehler, R.R. Eitenmiller and C.K. Kvien. 1993. Fatty Acid Composition and Tocopherol Content of Drought Stressed Florunner Peanuts. Peanut Science 20:2124

Hinds, M.J. 1995. Fatty Acid Composition of Caribbean-Grown Peanuts (Arachis hypogea L.) at Three Maturity Stages. Food Chemistry 53:7-14

Holaday, C.E. and L. Pearson. 1974. Effects of Genotype and Production Area on the Fatty Acid Composition, Total Oil and Protein in Peanuts. Journal of Food Science 39(6):12061209.

Ingale, S. and S.K. Shrivastava. 2011. Nutritional Study of New Variety of Groundnut (Arachis hypogea L.) JL-24 Seeds. African J. of Food Science 5(8):490-498

Ishag, H.M. 2000. Phenotypic and Yield Response of Irrigated Groundnut Cultivars in a Hot Environment. Exp. Agric. 36: 303-312.

Isleib, T.G., B.L. Tilman, H.E. Patte, T.H. Sanders, K.W. Hendrix and L.O. Dean. 2008. Genotype-by-Environment Interaction for Seed Composition Traits of Breeding Lines in the Uniform Peanut Performance Test. Peanut Science 35:130-138

Jordan, D.L., S. Danesha, L.Carley, C. Dharmasri, B.S. Turner, R.L.Brandenburg and G.B. Michael. 2008. Peanut response to Planting Date and Potential of Canopy Reflectance as an 
Indicator of Pod Maturation. Agronomy Journal 100:376380

Kaba, J.S., K.Ofori and F.K. Kumaga. 2014. Inter-Relationships of Yield and Components of Yield at Different Stages of Maturity in Three Groundnuts (Arachis hypogea L.) Varieties. International J. of Life Science Research 2(1):4348

Knauft, A., A.J. Norden and D.W. Gorbet. 1986. The Effect of Three Digging Dates on Oil Quality, Yield, and Grade of Five Peanut Genotypes Grown without Leaf spot Control. Peanut Science 13: 86-89

Lim, E.S and O. Hamdan.1984. The Reproductive Character of Four Varieties of Groundnuts (Arachis hypogea L.) Pertanica 7:25-31

Lu, K.C., M.S. Yeh, K.H. Yang and H.S. Lu. 1997. Effects of Genotype, Population Density and Harvest Date on Yield and Quality of Peanut. J. of Agric. Res. China 46(2):116-131

Mixon, A.C and W.D. Branch. 1985. Agronomic Performance of a Spanish and Runner Cultivar Harvested at Six Different Digging Intervals. Peanut Science 12:50-54

Önemli, F. 2012. Impact of Climate Change on Oil Fatty Acid Composition of Peanut (Arachis hypogea L.) in Three Market Classes. Chilean J. Agri. Res. 72(4):383-488

Park, C.K and J.H. Oh. 1992. Effect of Cultural Practice and Harvest Time on Yield Components of Peanut. Korean J. Crop Science 37(4):347-354

Pattee, H.E., J.C. Wynne, T.H. Sanders and A. Mschubert. 1980 Relation of the Seed/Hull Ratio to Yield and Dollar Value in Peanut Production. Peanut Science 7:74-77

Raheja, R.K., S.K. Battai, K.L. Ahuja, K.S. Labana and M. Singh. 1987. Comparison of Oil Content and Fatty Acid Composition of Peanut Genotypes Differing in Growth Habit. Plant Foods for Human Nutrition 37:103-108
Rahmianna, A.A., A. Taufiq and E. Yusnawan. 2009. Pod Yield and Kernel Quality of Peanut Grown Under Two Different Irrigations and Two Harvest Times. Indonesian $\mathrm{J}$. of Agriculture 2(2)103-109

Rowland, D.L., R.B. Sorensen, C.L. Butts and H.W. Faircloth. 2006. Determination of Maturity and Degree Day Indices and Their Success in Predicting Peanut Maturity. Peanut Science 33:125-136

Sanders,T.H., E.J. Williams, A.M. Schubert and H.E. Pattee. 1980. Peanut Maturity Method Evaluations. I.Southeast Peanut Science 7:78-82

Sattayarak, S. 1997. Effects of Harvesting Dates on Different Characters and Seed Quality of Peanut Grown in Southern Thailand. http://agris.fao.org/agris-search/.do?recordID= TH2000000950

Singh, F. and D.L. Oswalt. 1995. Groundnut Production Practices. ICRISAT. SAT, e-journal 9:29

Young, C. T., M. E. Manson, R. S. Matlock and G. R. Waller. 1972. Effect of Maturity on the Fatty Acid Composition of Eight Varieties of Peanut Grown at Parkins, Oklahoma in 1968. JAOCS 49:314-317

Young, C.Y. and R.E. Worthington. 1974. Fatty Acid Composition of Spanish Peanut Oil as Influenced by Planting Location, Soil Moisture Conditions, Variety, and Season. AOCS 51:312-315

Young, J. H., N.K. Person, J.O. Donald, and W.D. Mayfield.1982. Harvesting, Curing and Energy Utilization, pp.458-485. In H.E. Pattee and C. T. Young (eds). Peanut Science and Technology. Amer. Peanut Res. Educ. Society Inc., Yoakum. TX, USA.

Wright, F.S. and D.M. Porter. 1991. Early Leaf Spot of Peanuts: Effect of Conservation Tillage Practices on Disease Development. Peanut Science 8:72-75 